A.D. Baxter BM BS FRCPC FFARCS, *

S. Laganière PhD, $†$ B. Samson MD FRCPC, ${ }^{*}$ I.J. McGilveray PhD, $\dagger$ K. Hull RN*

\title{
A dose-response study of nalbuphine for post- thoracotomy epidural analgesia
}

The analgesic efficacy and side-effects of epidural nalbuphine $\left(0.075-0.3 \mathrm{mg} \cdot \mathrm{kg}^{-1}\right)$ were conipared with epidural morphine $0.1 \mathrm{mg} \cdot \mathrm{kg}^{-1}$ in a randomised double-blind study in postthoracotomy patients. The drugs were administered via a lumbar epidural catheter one hour before the end of surgery. Efficacy was assessed using visual analogue pain scores and supplementary iv fentanyt requirements; respiratory function was studied with an inductive plethysmograph and arterial blood gas analysis; and plasma nalbuphine levels were measured.

Pain scores and fentanyl supplementation were lowest in the morphine group $(P<0.01)$. No dose-response effect was apparent in the nalbuphine dose-range studied. Respiratory depression was more common in patients receiving morphine (higher mean $\mathrm{PaCO}_{2} P<0.01$, more frequent apnoeas $>15 \mathrm{sec}$ $P<0.05$, and incidence of $\mathrm{PaCO}_{2}>50 \mathrm{mmHg}$ requiring naloxone $P<0.011$. There were no differences in haemodynamic variables, sedation, or orher side-effects among the groups. The pharmacokinetic profile of epidural nalbuphine. was similar to that seen with rapid iv injection. The results indicate that, relative to morphine, lumbar epidural nalbuphine is an ineffective analgesic after thoracotony. Despite the lower incidence of respiratory depression its administration by this route cannot be recommended.

L'efficacité et les effets secondaires de la nalbuphine $10,075-$ $0.3 \mathrm{mg} \cdot \mathrm{kg}^{-1}$ ) furent comparés à la morphine épidurale 0,1

\section{Key words}

ANAESTHETIC TECHNIQUES: epidural; ANALGESICS: morphine, nalbuphine; PAIN: postoperative.

From the Department of Anaesthesia, Ottawa General Hospital" and the Bureau of Drug Research, Health Protection Branch, Tunney's Pasture, Ottawa. $\dagger$

Address correspondence to: Dr. Alan D. Baxter, Department of Anaesthesia, Ottawa General Hospital, 50I Smyth Road, Ottawa, Ontario KIH 8L6.

Presented in part at the ASA Annual Meeting, New Orleans October 1989.

Accepted for publication 30th October, 1990 $m g \cdot \mathrm{kg}^{-1}$. Les patients furent traités au hasard et à double-insue après une thoracotomie. Les opioides furent administrés par voie épidurale une heure avant la fin de la chirurgie. L'efficacité du traitement fut évaluée ò l'aide d'une échelle analogue visuelle de la douleur et par le besoin d'administration de fentanyl intraveneux supplémentaire ; la respiration fut évaluée par des gazométries et à l'aide d'un plethysmographe à induction. Les niveaux sanguins de nalbuphine furent mesurés.

La douleur et le besoin de fentanyl supplémentaire furemt moindres chez les patients traités à morphine $(P<0,01)$. On $n$ 'a pas noté de relation dose-effet chez les patients ayant reçu de la nalbuphine. L'incidence de dépression respiratoire fut plus marquée chez les patients traités à la morphine $\left(\mathrm{PaCO}_{2}\right.$ moyen plus élevé $P<0,01$, l'incidence plus fréquente d'apnée $>15$ sec $P<0,05$, et l'incidence de $\mathrm{PaCO}_{2}>50 \mathrm{mmHg}$ nécessitant du naloxone $P<0,01$ ). Aucune différence dans les paramètres hémodynamiques, le degré de sédation, et les autres effets secondaires ne fut observée entre ces groupes de patients. Le profil pharmacocinétique de la nalbuphine administrée par voie épidurale fur identique à celui de la nalbuphine administrée par voie intravéneuse. Les résultats indiquent qu'après une thoracotomie, la nalbuphine épidurale est un analgésique moins efficace que la morphine. Malgré une incidence de dépression respiratoire moins marquée, l'usage de la nalbuphine par voie épidurale ne peut être recommandé pour controler la douleur post-opératoire après une thoracotomie.

Epidural opioids provide effective postoperative analgesia, but may have undesirable side-effects such as pruritus, urinary retention, nausea and vomiting, and most importantly respiratory depression.' The incidence of severe respiratory depression is low, ${ }^{2}$ but mild carbon dioxide $\left(\mathrm{CO}_{2}\right)$ retention and abnormal respiratory patterns $^{3}$ are seen more frequently. This occurs especially in patients needing larger doses of opioids to produce acceptable analgesia, for example following thoracotomy ${ }^{3}$ or upper abdominal surgery. ${ }^{4}$ Most patients come to little harm from mild $\mathrm{CO}_{2}$ retention, but this represents a reduction of respiratory reserve and occasionally progresses to more severe depression.

Since the original description of the analgesic efficacy 
of intraspinal morphine, many opioids have been administered intrathecally or epidurally in attempts to reduce the incidence of side-effects. With lipophilic agents such as fentanyl ${ }^{5}$ and meperidine, ${ }^{6}$ more of the epidurally administered drug is thought to enter the spinal cord and blood vessels leaving less drug in the cerebrospinal fluid (CSF) for cephalad migration, ${ }^{7-9}$ and less delayed respiratory depression is observed.' Because of their antagonist properties at the mu receptors, ${ }^{10}$ agonist/ antagonist opioids produce fewer mu-mediated sideeffects. If they retain good agonist properties, they can be useful alternatives to morphine.

Nalbuphine hydrochloride is a lipophilic agonistantagonist opioid with analgesic potency comparable to morphine when administered intramuscularly ${ }^{\text {"I }}$ or intravenously, ${ }^{12}$ Plateau effect on respiratory depression has been demonstrated with increasing iv doses of nalbuphine. ${ }^{13}$ When given intrathecally in rats it has been found to produce prolonged analgesia. ${ }^{14}$ These properties suggested that nalbuphine might be a useful epidural analgesic which would produce less respiratory depression than morphine. Recent abstracts reported the efficacy of $10 \mathrm{mg}$ nalbuphine administered epidurally in patients after thoracic ${ }^{15}$ and abdominal surgery, ${ }^{16}$ but there has been no report of a clinical dose-response study.

This double-blind study, which was approved by the hospital Human Experimentation Committee, was designed to establish the analgesic efficacy, incidence of side-effects, and pharmacokinetic disposition of four different doses of epidural nalbuphine relative to epidural morphine.

\section{Methods}

\section{Patient selection}

The 52 patients aged 21-74 yr, had body-mass index $<30 \mathrm{~kg} \cdot \mathrm{m}^{-2}$, ASA physical status I-IIl, no history of chronic narcotic consumption, and no evidence of hepatic or renal dysfunction. These patients underwent elective thoracotomy for lobectomy, pneumonectomy, open lung biopsy, or hiatus hernia repair.

\section{Treatment allocation}

An explanation of the risks and benefits of the study was given, and informed consent was obtained. Each of the four consecutive phases of the study comprised 13 patients, ten of whom received epidural nalbuphine and three received epidural morphine, the drug treatment being assigned randomly using a computer-generated table known only to the hospital pharmacy. The first phase evaluated the lowest dose of nalbuphine, and the investigators did not move to the next higher dose until the planned number of patients in the lower dose phase (including controls) had been completed, and the efficacy and safety data had been reviewed by the investigators.
Preservative-free lyophilized nalbuphine was supplied by DuPont Pharmaceuticals and was reconstituted in saline by the hospital pharmacy into vials bearing only the patient's study number.

All patients received $0.15 \mathrm{ml} \cdot \mathrm{kg}^{-1}$ epidural solution, with the following drug concentration and mass in the four nalbuphine groups:

Group A - $0.5 \mathrm{mg} \cdot \mathrm{ml}^{-1}, 0.075 \mathrm{mg} \cdot \mathrm{kg}^{-1}$

Group B $-1.0 \mathrm{mg} \cdot \mathrm{ml}^{-1}, 0.15 \mathrm{mg} \cdot \mathrm{kg}^{-1}$

Group C $-1.5 \mathrm{mg} \cdot \mathrm{ml}^{-1}, 0.225 \mathrm{mg} \cdot \mathrm{kg}^{-1}$

Group D $-2.0 \mathrm{mg} \cdot \mathrm{ml}^{-1}, 0.3 \mathrm{mg} \cdot \mathrm{kg}^{-1}$

Patients in group $\mathrm{E}$ received $0.15 \mathrm{ml} \cdot \mathrm{kg}^{-1}$, i.e., $0.67 \mathrm{mg}$. $\mathrm{ml}^{-1}$ or $0.1 \mathrm{mg} \cdot \mathrm{kg}^{-1}$ of preservative-free epidural morphine.

\section{Anaesthesia}

Preoperative investigations included haemoglobin concentration, platelet count, electrolyte concentrations, urinalysis, ECG, CXR, pulmonary function tests, and arterial blood gas analysis. Pre-medication was with diazepam $0.1 \mathrm{mg} \cdot \mathrm{kg}^{-1}$ orally $1.5 \mathrm{hr}$ preoperatively. Before induction of general anaesthesia, a radial arterial cannula and lumbar (level 2-3 or 3-4) epidural catheter were inserted. The epidural position of the catheter was confirmed using a $5 \mathrm{ml}$ test dose of lidocaine $\mathrm{CO}_{2} 2 \%$ with epinephrine $1: 200,000$, followed by a further $5 \mathrm{ml}$ increment to produce a convincing sensory block.

Patients were monitored with ECG, peripheral nerve stimulator, oximeter, and mass spectrometer. General anaesthesia was induced with fentanyl $2-3 \mu \mathrm{g} \cdot \mathrm{kg}^{-1}$, thiopentone $3-5 \mathrm{mg} \cdot \mathrm{kg}^{-1}$, and succinylcholine $1.5 \mathrm{mg}$. $\mathrm{kg}^{-1}$, and airway management was by tracheal tube and bronchial blocker or double-Iumen bronchial tube Anaesthesia was maintained with nitrous oxide, oxygen, isoflurane, pancuronium, and additional fentanyl as required to a maximum of $5 \mu \mathrm{g} \cdot \mathrm{kg}^{-1}$ for the anaesthetic period. Muscle relaxation was reversed with neostigmine or edrophonium and atropine. Extubation occurred in the operating room or shortly after arrival in the recovery room.

\section{Pharmacokinetics}

Approximately one hour before the end of surgery, the study medication was injected epidurally over two minutes. Blood samples were taken immediately before and at $5,10,15,30 \mathrm{~min}, 1,2,4,6,8$, and $12 \mathrm{hr}$ after injection for nalbuphine assay. Arterial blood ( $5 \mathrm{ml}$ in EDTA) was centrifuged and plasma stored at $-20^{\circ} \mathrm{C}$ until analysed. Nalbuphine plasma concentrations were measured using high performance liquid chromatography with an electrochemical detection technique. ${ }^{17}$ The assay was validated over the range of the standard curve, and the lower limit of quantitation was $\mathrm{I} \mathrm{ng} \cdot \mathrm{ml}^{-1}$ (coefficient of variation $12 \%$ ) using $1 \mathrm{ml}$ of plasma. 


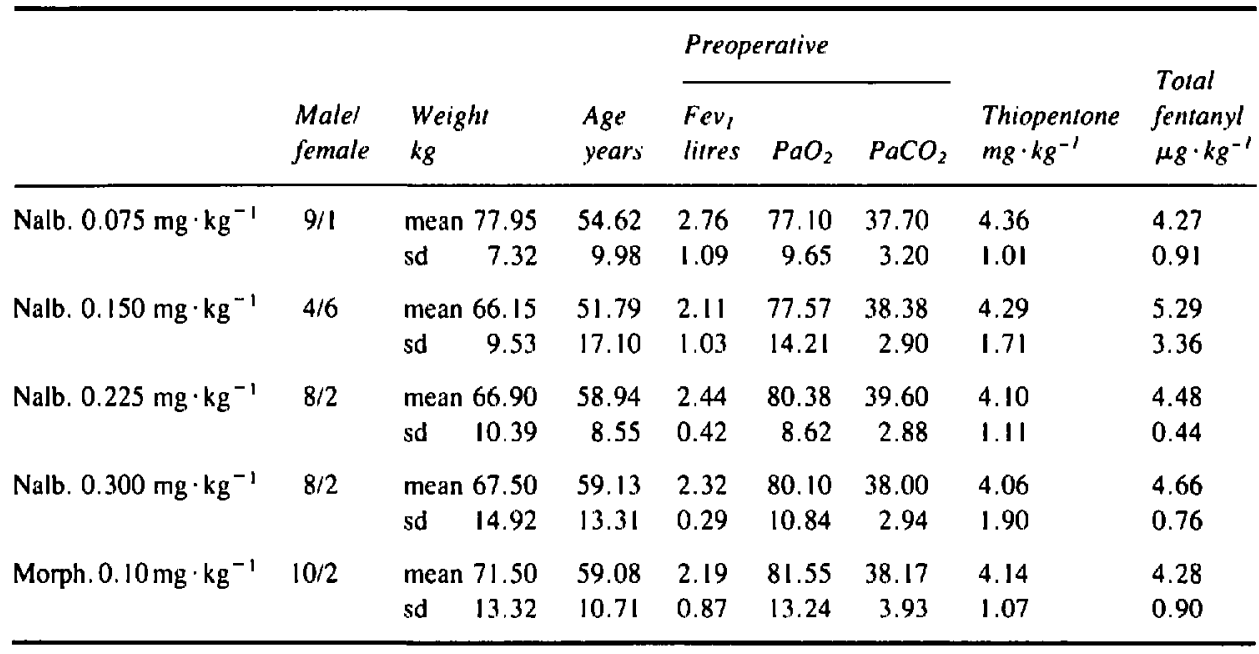

\section{Postoperative analgesia and measurements}

Patients remained in the recovery room for $24 \mathrm{hr}$. Additional analgesia was self -titrated by the patient using a patient-controlled analgesia pump (Bard Harvard PCA) with $20 \mu \mathrm{g}$ increments of fentanyl, a lockout time of five minutes, and a maximum dose of $160 \mu \mathrm{g} \cdot \mathrm{hr}^{-1}$. Oxygen saturation was monitored continuously and arterial blood gases were analyzed every two hours for $24 \mathrm{hr}$. Pain, sedation, pruritus, and nausea and vomiting were recorded hourly for $12 \mathrm{hr}$, and then two-hourly for a further $12 \mathrm{hr}$ by recovery room nurses, trained in the use of the appropriate scales, who were unaware which study agent had been administered. Pain intensity was scored by the patient on a visual analogue scale (zero $=$ no pain to ten $=$ agonizing pain). Sedation was assessed using a six-point scale (one $=$ mostly awake to six $=$ unarousable), and pruritus, nausea and vomiting, with a five-point scale (one $=$ none to five $=$ severe). ${ }^{18}$ Heart rate and blood pressure were monitored and all adverse effects were recorded.

Respiratory depression was defined as an arterial $\mathrm{PaCO}_{2}>50 \mathrm{mmHg}$ at any time postoperatively. If this occurred, then naloxone, $1 \mu \mathrm{g} \cdot \mathrm{kg}^{-1}$ bolus followed by a 1 $\mu \mathrm{g} \cdot \mathrm{kg}^{-1} \cdot \mathrm{hr}^{-1}$ infusion, was administered.

Respiratory pattern was monitored using an inductive plethysmograph (Vitalog). The data were stored in a micro-processor for later analysis. The plethysmograph was calibrated for normal and large tidal volumes with the patient breathing through a Wright's respirometer (BOC). Calibration was verified by having the patient perform vital capacity manoeuvres through a Spiroscreen 2120 respirometer (Gould), and this was repeated before the end of the plethysmograph monitoring at the end of the study to check for base-line drift. The plethysmograph data were later analyzed by computer and verified by comparison with a graphical print-out of the respiratory pattern. Periods of apnoea (tidal volume $=0 \mathrm{ml}$ ) lasting longer than $15 \mathrm{sec}$, slow respiratory rate $<10$ breaths $\mathrm{min}^{-1}$ lasting more than five minutes, and oxygen desaturation $<90 \%$ were noted.

\section{Statistical analysis}

Demographic data were analyzed using one-way analysis of variance (ANOVA) or Chi-squared analysis as appropriate. The 24-hr study period was divided into four-hour periods, and the recorded variables were averaged for each period. An ANOVA for repeated measures was used to detect treatment and time effects for visual analogue pain scores and analgesic supplementation. If the test was significant, and no interaction was detected, the NeumanKeuls procedure was used to compare all possible pairs of means. A least squares regression analysis was used to describe the relationship of the kinetic variables at different dose levels. ${ }^{19}$ In cases of non-equal variance, weighted regression was applied to the analysis

Because of the low incidence of side-effects in each nalbuphine group, the total incidence in patients receiving nalbuphine was compared with that in the morphine group using Chi-square analysis. Plethysmographic data were analysed using Chi-square analysis or Fisher exact test comparing the morphine group with the combined nalbuphine groups. Statistical significance was set at $P<$ 0.05 .

\section{Results}

\section{Demographic data}

There were no significant differences in age, weight, and preoperative pulmonary function among the five groups, nor in the doses of thiopentone or fentanyl received during anaesthesia (Table I). Salbutamol, aminophylline, nitroglycerin, digoxin, beta-blockers, calcium channel block- 
FOUR-HOUR VAS PAIN SCORE (Mean \pm SD)

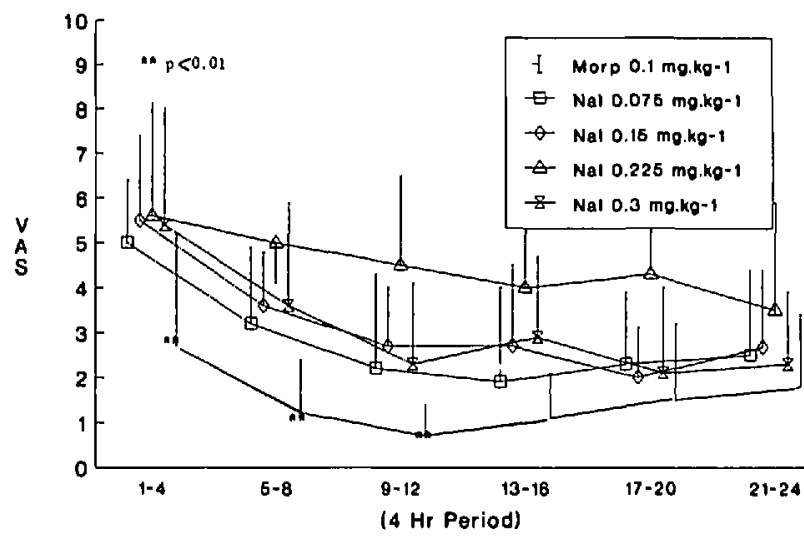

FIGURE 1 Four- hour visual analogue pain scores (VAS).

ers, and histamine-2 blockers were administered as clinically indicated; while the pharmacokinetic disposition of nalbuphine might have been affected by some of these drugs, their distribution was random among the groups.

\section{Analgesic efficacy}

The total pain scores over the 24 -hr study period differed among the groups. Compared with each of the nalbuphine groups, total pain score was lowest in the morphine group (mean $33 \pm 22 \mathrm{SD}, P<0.01$ ), and highest in the 0.225 $\mathrm{mg} \cdot \mathrm{kg}^{-1}$ nalbuphine group $\mathrm{C}(103 \pm 43, P<0.01)$, compared with group A $(63 \pm 38)$, group B $(70 \pm 20)$, and group $\mathrm{D}(70 \pm 27)$.

The mean pain scores for each four-hour period are shown in Figure I. In each of the first three periods, the morphine group had a lower pain score than each of the nalbuphine groups, despite the patients having access to supplementary fentanyl.

The total $24 \mathrm{hr}$-dose of supplementary fentanyl differed among the groups. The morphine-treated patients used less fentanyl $(551 \pm 359 \mu \mathrm{g}, P<0.01)$ than patients in any of the nalbuphine groups. The patients in the nalbuphine $0.3 \mathrm{mg} \cdot \mathrm{kg}^{-1}$ group $D$ used less fentanyl (1085 $\pm 325 \mu \mathrm{g}, P<0.01$ ) than those in the other nalbuphine groups (group A $1407 \pm 572$, group B $1488 \pm$ 453 , group C $1467 \pm 627 \mu g$ ).

The mean fentanyl dose for each four-hour period is shown in Figure 2. The mean dose in the morphine group was consistently the lowest in each period, and was significantly lower $(P<0.01)$ than in each nalbuphine group at all times except at $9-12$ and $21-24 \mathrm{hr}$ relative to the $0.3 \mathrm{mg} \cdot \mathrm{kg}^{-1}$ nalbuphine group. There were no significant differences in fentanyl requirements among

\section{FENTANYL SUPPLEMENTATION} (Mean \pm SD)

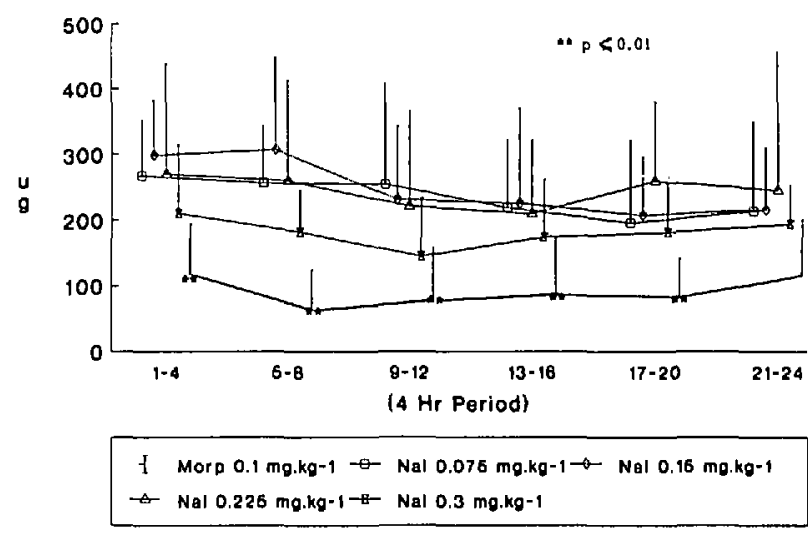

FIGURE 2 Fentanyl supplementation.

the four nalbuphine groups, and there were no increases with time.

\section{Respiratory function}

Mean $\mathrm{PaCO}_{2}$ was higher $(P<0.01)$ in the morphine group during the first two time periods (Figure 3 ), after which there was a significant decrease $(P<0.01)$ with time in that group. Naloxone was administered 10 more patients with $\mathrm{PaCO}_{2}>50 \mathrm{mmHg}(P<0.01)$ in the morphine group (five of eight patients) than in the nalbuphine groups (none in groups $A$ and $B$, three of four patients in group $C$, while one patient in group $D$ had $\mathrm{PaCO}_{2}>50 \mathrm{mmHg}$ but did not receive naloxone). Naloxone was not always given when $\mathrm{PaCO}_{2}>50 \mathrm{mmHg}$ because of the general well-being of individual patients, cardiovascular stability, and adequate oxygenation and level of conciousness. No patient required ventilatory support because of respiratory depression. There were no differences in the incidence of episodes of desaturation, all patients received supplementary oxygen as required. In all groups, abnormalities of respiratory pattern were most frequent between $5-12 \mathrm{hr}$; more patients receiving morphine $(50 \%)$ had apnoeas $(P<0.05)$, and while the frequency of apnoeas $\left(0.78 \pm 1.44 \mathrm{hr}^{-1}\right)$ and periods of slow rate $\left(0.7 \pm 2.34 \mathrm{hr}^{-1}\right)$ were highest in the patients receiving morphine they did not reach statistical significance. However, the highest incidence of apnoeas in a single period occurred in group D (in $66 \%$ of patients) at 17-20 hr, and the highest frequency of periods of slow respiratory rate in a single period $\left(1.57 \pm 2.66 \mathrm{hr}^{-1}\right)$ occurred in the same group at 13-16 hr.

\section{Haemodynamic variables}

Mean arterial pressure and heart rate were consistently 


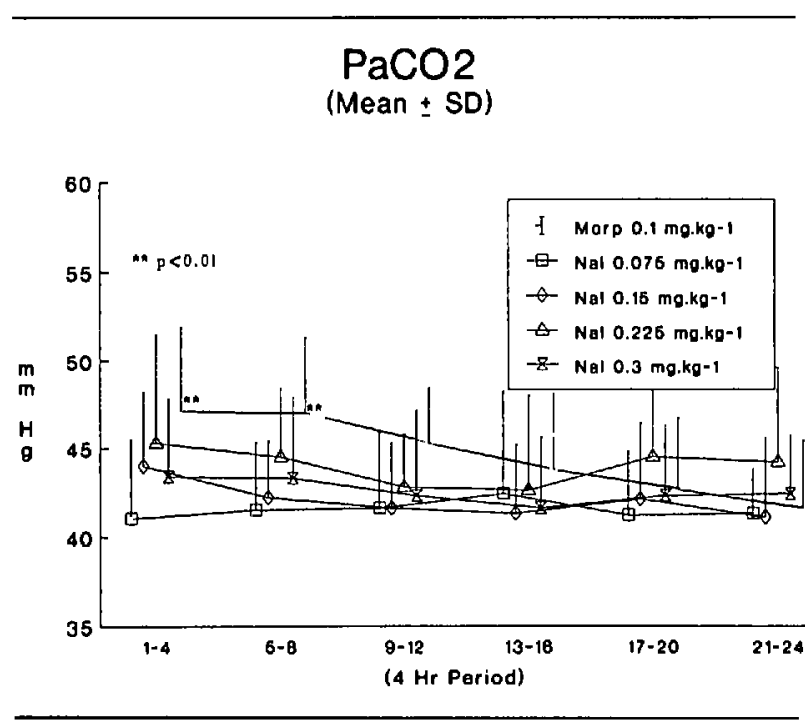

FIGURE 3 Mean $\mathrm{PaCO}_{2} \pm \mathrm{SD}$.

higher in each group during the first four-hour period than subsequently, but there were no differences among the five groups.

\section{Pharmacokinetic analysis}

The concentration-time curves of nalbuphine following epidural bolus (Figure 4) were fitted to two or three exponentials using the Powell weighted least squares algorithms ${ }^{20}$ run with the program SIPHAR (Simed, France). Nalbuphine distributed very rapidly in the systemic circulation, usually reaching peak concentrations within ten minutes. The pharmacokinetic variables derived using a non-compartmental analysis approach are shown in Table II.

\section{Adverse effects}

There were no differences in the incidence of adverse effects between patients receiving morphine or nalbuphine. Pruritus (Table III) occurred in 33\% of morphinetreated patients, while hypertension was equally frequent in all groups. The incidence of nausea was similar with the two drugs. Other adverse events included restlessness (three patients), and psychosis (one patient), all occurring

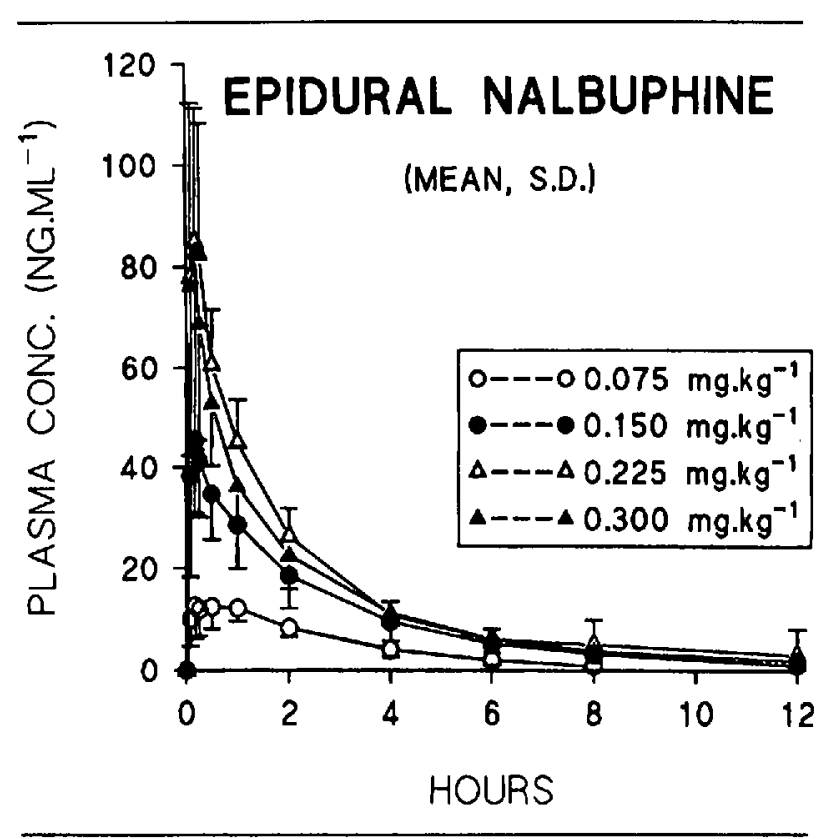

FIGURE 4 Plasma concentrations of nalbuphine after epidural administration.

in nalbuphine patients. Sedation scores were similar among the five groups.

\section{Discussion}

Nalbuphine hydrochloride is a lipophilic agonist/ antagonist opioid reported to be approximately equipotent with morphine at doses up to $0.15 \mathrm{mg} \cdot \mathrm{kg}^{-1} \mathrm{im}^{11}$ or $\mathrm{iv}^{12}$. Its pharmacology suggested that it might have potential advantages as an intraspinal analgesic. The analgesic efficacy of intrathecal nalbuphine has been studied in rats, ${ }^{14}$ while reports of studies in patients have suggested good analgesic efficacy of $10 \mathrm{mg}$ epidural nalbuphine after thoracic surgery ${ }^{15}$ compared with placebo, and after abdominal surgery compared with epidural morphine. ${ }^{16}$ The apparent duration of action was $9.2^{15}$ or $6.4^{16} \mathrm{hr}$ and the incidence of pruritus, nausea, and urinary retention was similar to $\mathrm{im}$ meperidine, ${ }^{15}$ and less than epidural morphine. ${ }^{16}$ The greater lipophilicity of nalbuphine compared with morphine should result in more of the

TABLE II Pharmacokinetic variables of four doses of nalbuphine (mean \pm SD)

\begin{tabular}{lllllll}
\hline $\begin{array}{l}\text { Dose } \\
M g \cdot k g^{-L}\end{array}$ & $\begin{array}{l}\text { Clearance } \\
L \cdot g^{-1} \mathrm{~kg}^{-1}\end{array}$ & $\begin{array}{l}A l c_{\infty} \\
n g \cdot h \cdot \mathrm{ml}^{-1}\end{array}$ & $\begin{array}{l}C_{\max } \\
n g \cdot \mathrm{ml}^{-1}\end{array}$ & $\begin{array}{l}T_{\max } \\
h\end{array}$ & $\begin{array}{l}V D \beta \\
l \cdot \mathrm{kg}^{-1}\end{array}$ & $\begin{array}{l}t_{j} \beta \\
h\end{array}$ \\
\hline Nal 0.075 & $1.7 \pm 0.4$ & $47 \pm 12$ & $14.3 \pm 5.1$ & 0.50 & $5.0 \pm 1.3$ & $2.1 \pm 0.5$ \\
Nal 0.15 & $1.4 \pm 0.5$ & $119 \pm 38$ & $48.2 \pm 16.1$ & 0.17 & $4.5 \pm 1.1$ & $2.3 \pm 0.5$ \\
Nal 0.225 & $1.3 \pm 0.2$ & $176 \pm 26$ & $96.3 \pm 28.2$ & 0.14 & $4.4 \pm 1.4$ & $2.4 \pm 0.7$ \\
Nal 0.3 & $1.8 \pm 0.4$ & $168 \pm 33$ & $89.1 \pm 36.5$ & 0.19 & $8.1 \pm 4.0$ & $3.0 \pm 1.6$ \\
\hline
\end{tabular}

For each dose, $n=10$. 


\begin{tabular}{|c|c|c|c|c|c|}
\hline & Prurilus & Naused & $\begin{array}{l}\mathrm{CO}_{2} \\
\text { retention }\end{array}$ & $\begin{array}{l}\text { Hyper. } \\
\text { rension }\end{array}$ & Resilessness \\
\hline Nalbuphine $0.075 \mathrm{mg} \cdot \mathrm{kg}^{-1} n=10$ & 3 & 0 & 0 & 0 & 0 \\
\hline Nalbuphine $0.150 \mathrm{mg} \cdot \mathrm{kg}^{-1} n=10$ & 1 & 3 & 0 & 2 & 1 \\
\hline Nalbuphine $0.225 \mathrm{mg} \cdot \mathrm{kg}^{-1} n=10$ & 1 & 2 & $4(3 N)$ & 2 & 2 \\
\hline Nalbuphine $0.300 \mathrm{mg} \cdot \mathrm{kg}^{-1} n=10$ & 2 & 0 & 1 & 3 & 1 \\
\hline Morphine $0.10 \mathrm{mg} \mathrm{kg}^{-1} n=12$ & 4 & 2 & $8(5 N)^{*}$ & $\mathbf{I}$ & 0 \\
\hline
\end{tabular}

epidurally administered drug penetrating to the opioid receptors in the spinal cord, and less persisting in the CSF available for cephalad travel. In dogs, unlike morphine, intracerebroventricular injection of nalbuphine did not produce respiratory depression. ${ }^{21}$

Based on these earlier studies, epidural nalbuphine was expected to produce adequate post-thoracotomy analgesia and be relatively free from side effects, especially respiratory depression. However, analgesic efficacy relative to morphine was poor.

There was no change in pain scores or supplementary fentanyl requirements with time during the study to suggest that analgesia from the epidurally administered nalbuphine was declining, which would give an indication of duration of action, while this was apparent with morphine.

This study compared epidural nalbuphine and morphine, without a placebo group. Patients in our morphine group required $551 \pm 359 \mu \mathrm{g} \cdot 24 \mathrm{hr}^{-1}$, while those receiving nalbuphine used $1407 \pm 572$ (Group A), 1488 \pm 453 (Group B), $1467 \pm 627$ (Group C), and $1085 \pm$ 325 (Group D) $\mu \mathrm{g} \cdot 24 \mathrm{hr}^{-1}$. Intravenous fentanyl requirements reported for adequate analgesia include 100-125 $\mu \mathrm{g} \cdot \mathrm{hr}^{-1}$ (spinal, upper abdominal, and thoracic surgery, continuous infusion), ${ }^{22} 55.8 \pm 22 \mu \mathrm{g} \cdot \mathrm{hr}^{-1}$ and $2739 \pm$ $1191 \mu \mathrm{g} \cdot 24 \mathrm{hr}^{-1}$ (upper and lower abdominal surgery, PCA), ${ }^{23}$ and $1399 \pm 88 \mu \mathrm{g} \cdot 24 \mathrm{hr}^{-1}$ (upper abdominal surgery, PCA) ${ }^{24}$ Nalbuphine was therefore probably producing some analgesia at the highest dose, but this was inferior to that produced by epidural morphine.

The maximum plasma concentrations $\left(\mathrm{C}_{\max }\right)$ of nalbuphine measured after epidural administration (45.3 \pm $14.5 \mathrm{ng} \cdot \mathrm{ml}^{-1}$ ) were similar to those reported five minutes following a single $10 \mathrm{mg} i v$ its injection $(38.8 \pm 12.2$ $\left.\mathrm{ng} \cdot \mathrm{ml}^{-1}\right) .{ }^{25}$ For the first two or three hours after injection of the two highest doses, plasma concentrations were above $20 \mathrm{ng} \cdot \mathrm{ml}^{-1}$ which has been considered to produce considerable analgesia. ${ }^{26}$ The clearance of epidural nalbuphine was fast and was similar to the intravenous clearance $\left(1.64 \pm 0.38 \mathrm{~L} \cdot \mathrm{min}^{-1}\right)$ following a $10 \mathrm{mg}$ dose in healthy volunteers. ${ }^{25}$ The large volume of distribution reflects the high liposolubility of the drug, and this was largest with more variance at the highest dose level. As the volume of injection was kept the same, the nalbuphine concentration varied among the groups; at higher concentrations, perhaps a depot effect may have resulted, with a slower diffusion process explaining the apparent higher volume of distribution and lower $C_{\max }$. However, no visual solubility problems were observed during preparation of the solutions. The $\mathrm{C}_{\max }$ was linear with dose and the time at which $\mathrm{C}_{\max }$ occurred was similar at all dose levels, but was more variable at the highest dose. The terminal half-life was similar at all doses with concomitant changes in clearance and volume of distribution, and was similar to that measured in healthy volunteers $(2.3 \pm$ $0.34 \mathrm{hr}$ ) following iv administration. ${ }^{25}$

In spite of their higher fentanyl use, patients given nalbuphine had higher pain scores than those receiving morphine. These patients did not use even more fentanyl to reduce pain scores to values of the morphine group, and the amounts used were well below the maximum available from the PCA pump. Pain appreciation results from the effects of a nociceptive stimulus interacting with the emotional state of the individual. Morphine tends to produce an euphoric effect, while opioids with antagonist activity produce less euphoria and may produce dysphoria in some patients. ${ }^{10} \mathrm{It}$ is possible that this difference in effect on mood was responsible for the difference in pain scores.

Nalbuphine may have been injected too far from the appropriate spinal segments mediating the incisional nociceptive stimulus. The lumbar site was selected because of the greater safety and ease of access compared with a thoracic approach. Fentanyl is effective ${ }^{27}$ when injected at the lumbar level in appropriate dose and volume, and one might expect other lipophilic drugs such as nalbuphine to be effective when given at that site.

As expected, the incidence of respiratory depression was lower in patients given nalbuphine than in those receiving the morphine. The incidence of $\mathrm{PaCO}_{2}$ elevation with morphine was similar to that observed previously in post-thoracotomy patients. ${ }^{18}$ Despite administration of 
naloxone, the mean $\mathrm{PaCO}_{2}$ in the morphine group was higher for the first two four-hour periods than in the nalbuphine-treated patients, even though the latter received more supplementary fentanyl. The lower $\mathrm{PaCO}_{2}$ in the nalbuphine patients may have been the result of poorer analgesia, or of nalbuphine reversal of respiratory depression caused by the additional iv fentany ${ }^{28}$ administered in the nalbuphine groups. Abnormalities of respiratory pattem were more common in patients receiving morphine, but also occurred in patients in other groups and in patients without $\mathrm{CO}_{2}$ retention. Logistics prevented the recording of baseline sleep recordings, and all patients received intravenous fentanyl which may have affected respiratory drive.

Pruritus, and nausea and vomiting, occurred with similar frequency in all groups. Sedation has been reported with postoperative analgesia with nalbuphine ${ }^{11,23,30}$ but in this study it was comparable to that produced by epidural morphine. Restlessness and psychosis occurred only in patients receiving nalbuphine, and the occurrence of such dysphoric effects might preclude the use of doses higher than those studied here.

Only abstract reports ${ }^{15,16}$ have claimed efficacy of epidural nalbuphine after surgery, and it is difficult to examine the methodology in detail to account for the different findings. A recent study of lumbar epidural nalbuphine after thoracotomy also reported inadequate analgesia. ${ }^{31}$ Repeated injections of nalbuphine 10 or $20 \mathrm{mg}$ were used, and the patient population was small. A thoracotomy incision is a very strong painful stimulus requiring intense analgesia, available with a higher dose or more frequent administration of epidural morphine; ${ }^{32}$ morphine is clearly able to provide analgesia for this surgical site, while nalbuphine appears to be inadequate.

\section{Conclusion}

Under the conditions of this study none of the four dose levels of nalbuphine produced adequate analgesia when administered by the lumbar epidural route. Morphine was a superior epidural analgesic for thoracic incisional pain. Epidural nalbuphine produced a lower incidence of respiratory depression indicated by $\mathrm{CO}_{2}$ retention and episodes of transient apnoea, but respiratory depression requiring treatment with naloxone did occur. The incidence of other side-effects was similar in patients receiving epidural morphine. Nalbuphine does not appear to be an effective analgesic by the epidural route compared with morphine. It is more likely to have a role in the prevention of side-effects from epidural morphine. ${ }^{18}$

\section{Acknowledgements}

We are grateful to: our colleagues in the Anaesthesia Department and the Recovery Room nursing staff for their cooperation during this study; Drs. Belanger and Cre- peau, Division of Thoracic Surgery, for cooperation with this study on their patients; Sylvie Paquette for secretarial assistance; Dupont Pharmaceuticals for supplying the nalbuphine and a grant to cover operating expenses: Jeremy Hill BSc and Eric Ormsby MSc for statistical analysis; Nicole Beaudoin for technical assistance with analysis of plasma samples; Bard Canada for supplying a Bard Harvard PCA pump; and to Dr. R. Ellioll for assistance with computer programming.

\section{References}

1 Cousins MJ, Mather LE. Intrathecal and epidural administration of opioids. Anesthesiology 1984; 61: 276-310.

2 Rawal N. Arner S, Gustafsson LL. Allvin R. Present state of extradural and intrathecal opioid analgesia in Sweden. Br J Anaesth 1987; 59: 791-9.

3 Sandler AN, Chovaz $P$. Respiratory depression following epidural morphine: a clinical study. Can Anaesth Soc J 1986; 33: 542-9.

4 Madsen JV, Rybro L, Schurizek BA el al. Respiratory depression following postoperative analgesia with epidural morphine. Acta Anaesthesiol Scand 1986; 30: 417-20.

5 Lomessy A, Magnin C, Viale JP et al. Clinical advantages of fentanyl given epidurally for post-operative analgesia. Anesthesiology 1984; 61: 466-9.

6 Glynn CJ, Mather LE, Cousins MJ et al. Peridural meperidine in humans: analgetic response, pharmacokinetics, and transmission into CSF. Anesthesiology 1981; 55: 520-6.

7 Sjostrom S, Harrvig P, Persson P, Tamsen A. Pharmacokinetics of epidural morphine and meperidine in humans. Anesthesiology 1987; 67: 877-88.

8 Gourlay GK, Cherry DA, Plummer JL et al. The influence of drug polarity on the absorption of opioid drugs into CSF and subsequent cephalad migration following epidural administration: application to morphine and pethidine. Pain 1987; 31: 297-305.

9 Gourlay GK, Murphy TM, Plummer JL et al. Pharmacokinetics of fentanyl in lumbar and cervical CSF following epidural and intravenous administration. Pain 1989; 38: 253-9.

10 Offermeier $J$, Von Rooyer $J M$. Opioid drugs and their receptors, a summary of the present state of knowledge. S Afr Med J 1984; 66: 299-305.

11 Beaver WT, Feise GA. A comparison of the analgesic effect of intramuscular nalbuphine and morphine in patients with postoperative pain. J Pharmacol Exp Ther 1978; 204: 487-96.

12 Gal TJ, DiFazio CA, Moscicki J. Analgesic and respiratory depressant activity of nalbuphine: a comparison with morphine. Anesthesiology 1982; 57: 367-74. 
13 Romagnoli A, Keats AS. Ceiling effect for respiratory depression by nalbuphine. Clin Pharmacol Ther 1980 ; 27: 478-85.

14 Schmauss $C$, Doherty $C$, Yaksh TL. The analgesic effects of an intrathecally administered partial opiate agonist, nalbuphine hydrochloride. Eur J Pharmacol 1983; 86: 1-7.

15 Mok MS, Louis BW, Wong BF, Chan KW, Lipmann $M$. Epidural nalbuphine for the relief of pain after thoracic surgery. Anesth Analg 1985; 64: 258.

16 Wang JJ, Mok MS, Lipmann M. Comparative analgesic efficacy of epidural nalbuphine, butorphanol, meperidine, and morphine. Anesth Analg 1988; 67: S248.

17 Dube $L M$, Beaudoin N. Determination of nalbuphine by high performance liquid chromatography with electrochemical detection: application to clinical samples from post-operative patients. J Chromatography 1988; 427 : 113-20.

18 Baxter $A D$, Samson B. Penning $J$ et al. Prevention of epidural morphine-induced respiratory depression with intravenous nalbuphine infusion in post-thoracotomy patients. Can J Anaesth 1989; 36: 503-9.

19 Draper NR. Smith H. Applied regression analysis, 2nd edition. Wiley, New York, 1981; 110.

20 Powell MJD. The Powell method - an efficient method for finding the minimum as a function of several variables without calculating derivatives. Computer Journal 1964; 7: 155-62.

21 Henderson SK, Pellegrino DA, Peterson RD. Comparative effects of nalbuphine vs. morphine on ventilatory drive after intracerebroventricular administration in the awake dog. Anesthesiology 1986; 65: A279.

22 Holley FO, Van Steenis $C$. Postoperative analgesia with fentanyl: pharmacokinetics and pharmacodynamics of constant-rate i.v. and transdermal delivery. $\mathrm{Br} J$ Anaesth 1988; 60; 608-13.

23 Gourley GK, Kowalski SR, Plummer JL et al. Fentanyl blood concentration-analgesic response relationship in treatment of postoperative pain. Anesth Analg 1988; 67: 329-37.

24 Rosenberg PH, Heino A, Schein B. Comparison of intramuscular analgesia, intercostal block, epidural morphine, and on-demand-i.v.-fentanyl in the control of pain after upper abdominal surgery. Acta Anaesthesiol Scand 1984; 28 : 603-7.

25 Lo MW, Lee FH, Schary WL, Whimey CC Jr. The pharmacokinetics of intravenous, intramuscular, and subcutaneous nalbuphine in healthy subjects. Eur J Clin Pharmacol 1987; 33: 297-301.

26 Bullingham RES. Im Opioid AgonisUAgonist Drugs in Clinical Practice. Nimmo WS, Smith G (Eds.). Excerpta Medica, Amsterdam 1983, 115.

27 Wolfe MJ, Davies GK. Analgesic action of extradural fentanyl. Br J Anaesth 1980; 52: 357-8.
28 Moldenhauer $C C$, Roach $G W$, Finlayson $D C$ er al. Nalbuphine antagonism of ventilatory depression following high dose fentanyl anesthesia. Anesthesiology 1985; 62: 647-50.

29 Pugh GC, Drummond GB. A dose-response study with nalbuphine hydrochloride for pain in patients after upper abdominal surgery. Br J Anaesth 1987; 59: 1356-63

30 Penning JP, Samson B, Baxter AD. Reversal of epidural morphine induced respiratory depression and pruritus with nalbuphine. Can J Anaesth 1988; 35: 599-604.

31 Etches $R C$, Sardler $A N$. Analgesic affects of epidural nalbuphine in post-thoracotomy patients. Can J Anaesth 1989; 36: S156-7.

32 Stenseth $R$, Sellevold $O$. Breivik $H$. Extradural morphine for postoperative pain: experience with 1085 patients. Acta Anaesthesiol Scand 1985; 29: 148-56. 